\title{
New records of the archaic dolphin Agorophius (Mammalia: Cetacea) from the upper Oligocene Chandler Bridge Formation of South Carolina, USA
}

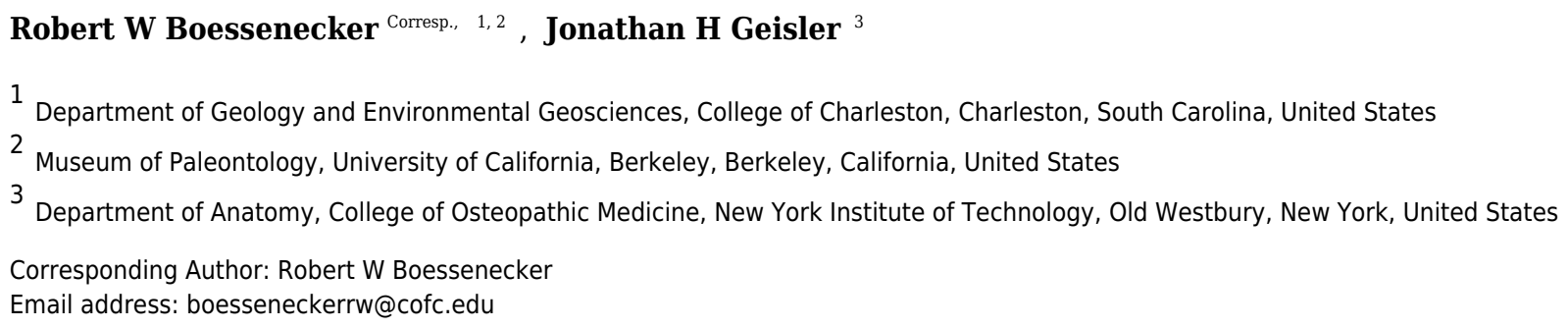

The stem odontocete Agorophius pygmaeus (Ashley Formation, lower Oligocene, South Carolina; 29.0-26.57 Ma) has been a critical point of comparison for studies of early neocete evolution owing to its early discovery as well as its transitional anatomy relative to archaeocete whales and modern odontocetes. Some time during the late nineteenth century the holotype skull went missing and has never been relocated; supplementary reference specimens have since been recently referred to the species from the Ashley Formation and the overlying Chandler Bridge Formation (upper Oligocene; 24.7-23.5). New crania referable to Agorophius sp. are identifiable to the genus based on several features of the intertemporal region. Furthermore, all published specimens from the Chandler Bridge Formation consistently share larger absolute size and a proportionally shorter exposure of the parietal in the skull roof than specimens from the Ashley Formation (including the holotype). Furthermore, these specimens include well-preserved ethmoid labyrinths and cribriform plates, indicating that Agorophius primitively retained a strong olfactory sense. These new crania suggest that at least two species of Agorophius are present in the Oligocene of South Carolina, revealing a somewhat more complicated taxonomic perspective. 
1 New records of the archaic dolphin Agorophius (Mammalia: Cetacea) from the upper

2 Oligocene Chandler Bridge Formation of South Carolina, USA

3

4 Robert W. Boessenecker ${ }^{1,2}$ \& Jonathan H. Geisler ${ }^{3}$

$5{ }^{1}$ Department of Geology and Environmental Geosciences, College of Charleston, 66 George

$6 \quad$ Street, Charleston, SC, 29424, USA

$7 \quad{ }^{2}$ University of California Museum of Paleontology, University of California, 1101 Valley Life

$8 \quad$ Sciences Building, Berkeley, CA, 94720, USA

$9{ }^{3}$ Department of Anatomy, College of Osteopathic Medicine, New York Institute of Technology,

10 Old Westbury, NY, 11568, USA

11 Corresponding Author: Robert W. Boessenecker (boesseneckerrw@cofc.edu)

\section{Abstract}

The stem odontocete Agorophius pygmaeus (Ashley Formation, lower Oligocene, South

Carolina; 29.0-26.57 Ma) has been a critical point of comparison for studies of early neocete evolution owing to its early discovery as well as its transitional anatomy relative to archaeocete whales and modern odontocetes. Some time during the late nineteenth century the holotype skull went missing and has never been relocated; supplementary reference specimens have since been recently referred to the species from the Ashley Formation and the overlying Chandler Bridge Formation (upper Oligocene; 24.7-23.5). New crania referable to Agorophius sp. are identifiable to the genus based on several features of the intertemporal region. Furthermore, all published specimens from the Chandler Bridge Formation consistently share larger absolute size and a proportionally shorter exposure of the parietal in the skull roof than specimens from the Ashley 
24 Formation (including the holotype). Furthermore, these specimens include well-preserved ethmoid labyrinths and cribriform plates, indicating that Agorophius primitively retained a strong olfactory sense. These new crania suggest that at least two species of Agorophius are present in the Oligocene of South Carolina, revealing a somewhat more complicated taxonomic perspective.

\section{Introduction}

The holotype skull of Agorophius pygmaeus consists of a partial cranium and tooth (MCZ 8761) collected in January 1847 by F.S. Holmes (Curator, College of Charleston Museum) and L.R. Gibbes (Professor, College of Charleston) from exposures of the Ashley Formation at Greer's Landing near Middleton Place Plantation west of Charleston, South Carolina. Owing to its transitional morphology between Eocene archaeocetes and modern odontocetes, early studies often referred to Agorophius as a key comparative taxon (Whitmore and Sanders, 1977:308-310). Poor taxonomic practices led to the treatment of the Agorophiidae as a wastebasket taxon for many disparate early odontocete species now placed in other such families as the Xenorophidae, although that practice has now largely been abandoned (Whitmore and Sanders, 1977; Fordyce, 1981; Godfrey et al., 2016). The holotype originally belonged to F.S. Holmes, and after some initial study by Louis Agassiz in 1848-1850, the specimen was loaned to Joseph Leidy in 1869; by 1907, the specimen was realized to be lost (see Fordyce, 1981; Godfrey et al., 2016). In 1980, the holotype tooth was rediscovered and described by R.E. Fordyce (1981), though the skull is still missing. Fordyce (1981) published a supplementary description of the skull based on high quality illustrations. 
47

Recently reported specimens of Agorophius have provided new reference specimens for the taxon as well as preserve aspects of the anatomy not represented in the now lost holotype cranium. These include ChM PV 4256, a partial skull and mandible with isolated teeth and associated postcrania from the Chandler Bridge Formation, and SC 2015.51.1, a partial skull from the Ashley Formation. The former specimen was identified and coded as Agorophius pygmaeus by Geisler and Sanders (2003) and figured by Godfrey et al. (2016); it remains undescribed. SC 2015.51.1 was described and referred to Agorophius pygmaeus by Godfrey et al. (2016). Godfrey et al. (2016) conducted a specimen-level cladistic analysis of Agorophius, and recovered a monophyletic Agorophius including these specimens and the holotype.

This study reports newly recovered specimens of Agorophius from the Chandler Bridge Formation include two incomplete skulls. These skulls raise questions about the identification of previously referred specimens of Agorophius and provide new information on ontogenetic variation and sensory anatomy in Agorophius.

\section{Materials and Methods}

Anatomical terminology follows Mead and Fordyce (2009) and Godfrey et al. (2013). All photographs were taken with a Canon EOS Rebel XS and $80 \mathrm{~mm}$ zoom lens.

Institutional Abbreviations: CCNHM, Mace Brown Museum of Natural History, College of Charleston, Charleston, South Carolina, USA; ChM, Charleston Museum, Charleston, South Carolina, USA; MCZ, Museum of Comparative Zoology, Harvard University, Cambridge, Massachusetts, USA; SC, South Carolina State Museum, Columbia, South Carolina, USA. 
71

\section{Geologic Background}

1

2

The new crania reported in this study (CCNHM 1921, 1922) were collected by Steven Hildenbrandt in May 2017 from a construction site (now developed) in the Coosaw Preserve subdivision of North Charleston, Charleston County, South Carolina (Fig. 1A-B). Specimens were collected in situ from the Chandler Bridge Formation exposed in an excavated pond. Other specimens collected from the same pond include a possible squalodelphinid dolphin skull and skeleton (CCNHM 2115) and a partial shell of the sea turtle Carolinachelys wilsoni (CCNHM 1903). Sediment associated with these skeletons consists of lightly consolidated, tan, silty, finevery fine friable sandstone, consistent with bed 2 of the Chandler Bridge Formation (Fig. 1C). Based on the lithology of this bed, its relationships to other facies, and micro- and macrofossils, Katuna et al. (1997) interpreted this bed forming in a bay or estuarine environment. At the Coosaw Preserve this bed was below the water level of the pond, thus observations of thickness, geometry, sedimentary structures, and ichnology were not possible.

The Chandler Bridge Formation is $24.7-23.5 \mathrm{Ma}$ in age based on ${ }^{87} \mathrm{Sr} /{ }^{86} \mathrm{Sr}$ ratios from the same unit and from the overlying Edisto Formation reported by Weems et al. (2016; see also Boessenecker and Fordyce, 2016:456-458). The shark assemblage reported from the Chandler Bridge Formation, most likely from the basal marine facies, is suggestive of inner to middle shelf depths and temperatures ranging from $20-25^{\circ} \mathrm{C}$ (Cicimurri and Knight, 2009). The billfish Aglyptorhynhcus similarly indicates middle shelf depths and temperatures of $20-24^{\circ} \mathrm{C}$ (Purdy et al., 2001; Fierstine and Weems, 2009). Overall deposition of the Chandler Bridge Formation reflects a regressive parasequence deposited over the Ashley Formation without a transgressive unit (Katuna et al., 1997), similar to other sequences further north on the Atlantic Coastal Plain 
93 with thin, entirely regressive parasequences are deposited under conditions of low subsidence 94 rate (Kidwell, 1993). The unconformity between the Ashley Formation and the Chandler Bridge

95 Formation represents approximately 2-3 million years (Weems et al., 2016). A rich assemblage

96 of marine vertebrates is now known from the Chandler Bridge Formation including sharks, bony

97 fish, an estuarine crocodile, freshwater and sea turtles, marine birds, cetaceans, and sirenians

98 (Whitmore and Sanders, 1977; Sanders et al., 1982; Erickson and Sawyer, 1996; Sanders and

99 Barnes, 2002; Cicimurri and Knight, 2009; Fierstine and Weems, 2009; Geisler et al., 2014;

100 Weems and Knight, 2013; Weems and Sanders, 2014; Ksepka, 2014; Churchill et al., 2016;

101 Godfrey et al., 2016; Weems and Brown, 2017).

102

103 Systematic Paleontology

104 Mammalia Linnaeus, 1758

105 Cetacea Brisson, 1762

106 Odontoceti Flower, 1867

107 Agorophiidae Abel, 1914

108 Agorophius Cope, 1895

109 Agorophius sp.

110 Figures 2-4

111 Material: CCNHM 1921, partial skull including dorsal parts of parietal, supraoccipital,

112 posterior part of frontal and incomplete right supraorbital process, partial ascending process of

113 right maxilla, posterior tip of right premaxilla, and ethmoid; CCNHM 1922, partial skull

114 including dorsal parts of parietal, supraoccipital, frontal, ethmoid, and a fragment of the 
115 ascending process of the right maxilla. Both specimens collected on June 19, 2017 by Steven 116 Hildenbrandt.

117 Locality: Coosaw Preserve, exposure of Chandler Bridge Formation in excavated pond 118 (now developed) on construction site, North Charleston, South Carolina, USA (Fig. 1). Detailed 119 locality information on file at CCNHM, available on request to qualified researchers.

120 Age: early Late Oligocene (Chattian), dated to $24.7-23.5$ based on ${ }^{87} \mathrm{Sr} /{ }^{86} \mathrm{Sr}$ ratios 121 reported from mollusks by Weems et al. (2016). Identification: CCNHM 1921 and 1922 preserve two features unique to Agorophius

123

124

125

126

127

128

129

130

131

132

133

134

135

136

137

\section{Description}

\section{Premaxilla}

In CCNHM 1922, the nasal process of the premaxilla (Fig. 2A-B) is present is and divided into a posterolateral plate and a posteromedial splint. Although the posterolateral plate is not preserved, 
138 its existence can be inferred from the sutural surface on the maxilla. The posteromedial splint is a

139 narrow, vertical, and posteriorly tapering wedge between the frontal (medially) and the

140 ascending process of the maxilla (laterally). A deeply incised premaxillary cleft is vertical,

141 parasagittally oriented, and presumably separated the posteromedial splint (preserved) from the

142 posterolateral plate (inferred). Part of the right nasal may be present but owing to damage it is

143 unclear if it what is observed is actually the medial edge of the premaxilla. Though broken, the

144 premaxilla transversely widens anteriorly based on the shape of the articular "buttress" for the

145 premaxilla on the maxilla.

\section{Maxilla}

148 The ascending process of the maxilla is transversely expanded, dorsoventrally thin and sheet-

149 like, and extends posteriorly to the level of the occipital shield apex (Fig. 2A-B). Medially, the

150 ascending process of the maxilla forms a vertical plate that abuts the posteromedial splint of the

151 premaxilla. This plate transitions anteriorly into a slightly raised platform that underlies the

152 premaxilla adjacent to the nares. A single, large and posteriorly directed dorsal infraorbital

153 foramina is present lateral to the posterior termination of the nasal, about $1 \mathrm{~cm}$ lateral to the

154 premaxilla. A vertical fissure separates the maxilla from the premaxilla.

\section{Frontal}

157 The median frontal suture is unfused in CCNHM 1922 and obliterated in CCNHM 1921 (Fig.

158 2A-B). The frontoparietal suture is transverse and $\mathrm{W}$-shaped with a median point, bilateral

159 anterior embayments, and an anterolaterally extending portion that contributes a small part to the

160 supraorbital process. The latter part of the parietal resembles the morphology in Ashleycetus 
161 planicapitis, although in that taxon this part of the parietal expands further anterolaterally

162 (Sanders and Geisler, 2016). Dorsally the frontal has a median, rectangular plateau outlined

163 laterally by the premaxilla, the parietal posteriorly, and the nasals anteriorly. The frontal is

164 anteriorly pointed with an anterolaterally facing articular surface for the nasal. In CCNHM 1921,

165 the frontal is more acutely pointed and the rectangular median plateau is proportionally narrower.

166 Given the higher degree of suture closure and inferred older ontogenetic stage of CCNHM 1921,

167 this suggests that the premaxilla and maxilla grow dorsomedially, at the expense of the frontal,

168 with age. Obviously this suggestion will be speculative until larger sample sizes are available.

169 Dorsally, the frontal is very porous in comparison to the occipital shield and the ascending

170 process of the maxilla.

171 A thin band of frontal was probably exposed posterior to the ascending process of the 172 maxilla in CCNHM 1921, but damage to the maxilla obscures the extent. The dorsal surface of 173 the supraorbital process of the frontal bears numerous radial, anteroposteriorly directed ridges 174 and grooves for the ascending process of the maxilla.

175 The frontal forms most of the ventral surface of the compound supraorbital process (Fig.

176 2E-F). The posterior edge is formed by the anterolateral wing of the parietal. Posterior to the

177 frontal groove the frontal is smooth and shallowly concave. This part bears a series of faint, 178 radially oriented (i.e. lateral to posterolaterally directed) vascular sulci that emanate from the 179 medial end of the orbit. The frontal groove is partially preserved in CCNHM 1921, widens from $1803 \mathrm{~mm}$ to about $9-10 \mathrm{~mm}$ laterally, is deeply concave in cross-section, and oriented $35-40^{\circ}$ from 181 the sagittal plane.

\section{Ethmoid}


184 (Fig. 2E-F). The ethmoid labyrinth is best seen on the left side of CCNHM 1922 (Fig. 2E, 4A).

185 There are two longitudinal ridges that separate 3 fossae; from dorsal to ventral they are: a larger

186 smooth-floored fossa for the dorsal nasal meatus, a middle and undulatory fossa with various

187 foramina, and a smooth but small fossa. Although not preserved, it is likely that these ridges

188 became more prominent anteriorly, thus forming more distinct ethmoturbinals and more discreet

189 nasal meatuses. The ethmofrontal suture is evident dorsally, and fused internally within the

190 olfactory peduncle canal. The canal is transversely narrow, anteroposteriorly long, and widens

191 anteriorly. Anteriorly the roof of the canal bears a few foramina with associated longitudinal

192 sulci. There are no apparent exits for these foramina on the dorsal side of the skull, and we

193 suspect that they drained the diploe of the frontal bone, as is seen in a protocetid and the basal

194 mysticete Coronodon havensteini (Godfrey et al., 2013; Geisler et al., 2017). Posteriorly the

195 olfactory peduncle canal narrows and has a deeply incised dorsal fissure (Fig. 2e, 4b).

196 The ethmoid also has a prominent median portion. In anterior view it present a broken,

197 dorsoventral partition that separates the right and left ethmoidal labyrinths. In CCNHM 1921,

198 only a median break remains to indicate where this median projection of ethmoid connected to

199 the rest of the skull (Fig. 2E-F); however, the dorsal part of this median projection is preserved

200 in CCNHM 1922 (Fig. 4b). On the right side, this median portion of ethmoid bears a transverse,

201 broken perforate shelf that forms part of the cribriform plate (Fig. 4A). Interestingly, it does not

202 appear to completely bridge the canal, unlike the morphology seen in archaeocetes, extant

203 mysticetes (Godfrey et al., 2013) and Squalodon (Godfrey, 2013). The plate bears a median,

204 posteriorly directed conical projection (=crista galli) 
206 CCNHM 1921, where it is developed as a narrow fissure (Fig. 2F, 4). Longitudinal sulci are

207 present in the anterior half of the canal. The ethmoturbinal recess has some poorly preserved

208 turbinates, but the labyrinth and recess are small and separated by a low ridge immediately

209 adjacent to the dorsal meatus. The preserved part of the meatus is a dorsally situated, lozenge-

210 shaped, smooth cavity.

211 Ventrally, the frontal descends to terminate at large, articular surfaces for the alisphenoid;

212 these facets are rectangular, face anteroventrally, and exhibit anteroposteriorly directed ridges

213 and furrows forming a mortised frontal-sphenoid suture. Posterior to this in CCNHM 1921, the

214 frontals form the anterodorsal margin of the endocranial surface with a median fissure-like

215 opening for the olfactory nerve canal.

216

217 Parietal

218 Dorsally each parietal forms a triangular exposure, and medially they are connected by an

219 anteriorly bowed, narrow band wrapping around the apex of the occipital shield (Fig. 2A-B). A

220 distinct crease occurs between the supraoccipital and the parietal. The frontoparietal suture in

221 CCNHM 1921 is open and anastomosing; the suture is more highly mortised and mostly closed

222 in CCNHM 1922 (Fig. 2A-B). The parietal at the midline is pinched between the supraoccipital

223 and frontal, and this exposure is reduced in CCNHM 1922, which we attribute to ontogenetic

224 development of cranial telescoping.

225 The lateral edge of the parietal is concave in dorsal view, forming the medial margin of

226 the temporal fossa; the anterolateral wing of the parietal extends along the posteromedial part of

227 the compound supraorbital process of the frontal and buttresses it ventrally. The intertemporal 
228 region of the skull is dorsally flat with a nearly contiguous surface with the frontal (Fig. 3A-B).

229 The intertemporal portions of the frontal and parietal are very cancellous in CCNHM 1922 (Fig.

230 2A). In CCNHM 1921, three small foramina are present on either side of the parietal (Fig. 2B),

231 though less clearly developed in CCNHM 1922. The lateral side of the braincase is broadly

232 concave and formed by the parietal, which posterodorsally forms the lateral part of the nuchal

233 crest and overhangs the temporal fossa. The frontoparietal suture is sigmoidal and anterodorsally

234 oriented in lateral view.

235

236 Supraoccipital

237 The occipital shield bears a triangular apex; the apex is somewhat more truncated in CCNHM

2381921 than in CCNHM1922. A nuchal tuberosity is present and developed as a flat, diamond-

239 shaped plateau at the apex. The occipital shield is transversely concave, and at the midline is

240 inclined posteroventrally from the plane formed by the frontoparietal 'table' approximately $48^{\circ}$

241 in CCNHM 1922 and 59 in CCNHM 1921.

242

243 Discussion

244

245 Olfactory anatomy

246 Several recent studies have investigated the anatomy of the ethmoid labyrinth and cribriform

247 plate in extinct and extant cetaceans, and surprisingly found that modern mysticetes maintain a

248 well-developed olfactory system complete with cribriform plate that differs little from

249 archaeocete ancestors (Thewissen et al., 2011; Godfrey et al., 2013). Modern odontocetes lack

250 such structures and as a result have probably lost their olfactory sense (Edinger, 1955; Berta et 
251 al., 2014). These anatomical changes are mirrored by molecular changes; cetaceans have a much

252 higher proportion of olfactory receptors that are pseudogenes than many other mammals

253 (Kishida et al., 2007; McGowen et al., 2008), and inactivation of individual genes is much more

254 prevalent among odontocetes than in mysticetes (Springer and Gatesy, 2017). Unlike extant

255 odontocetes, archaic Miocene odontocetes like Squalodon retain a cribriform plate and labyrinth

256 (Godfrey, 2013). Obfuscating these matters somewhat is the apparent lack of a cribriform plate

257 in xenorophids such as Albertocetus meffordorum and Inermorostrum xenops (Boessenecker et

258 al., 2017a, 2017b). It remains unclear whether the condition in xenorophids detected thus far

259 reflects true anatomy or postmortem taphonomic damage.

260 Skulls of Agorophius sp. reported herein shed new light on these matters, as Agorophius

261 is typically recovered on the odontocete stem in an intermediate position between the basal

262 position of xenorophids and later diverging Squalodon (Godfrey et al., 2016; Boessenecker et al.,

263 2017b). Both specimens (CCNHM 1921, 1922) preserve an ethmoid labyrinth and CCNHM

2641922 preserves an incomplete cribriform plate (Fig. 2E, 4). It is unclear whether or not the

265 cribriform plate completely or incompletely bridged the junction between the ethmoid labyrinth

266 and olfactory canal, owing to damage. Regardless, some degree of a cribriform plate is present in

267 Agorophius as well as later diverging stem odontocetes like Squalodon (Godfrey, 2013).

268 Clarification regarding the condition in xenorophids is needed, as the apparent absence would

269 imply two distinct losses of the cribriform plate, one due to lack of ossification (i.e. xenorophids)

270 and the other due to closure of the olfactory foramina (crown Odontoceti).

271

272 Cranial variation and stratigraphic origin of Agorophius specimens 
These newly described partial crania are incomplete but represent the first formally

274 described specimens of Agorophius from the Chandler Bridge Formation. CCNHM 1921 and

2751922 are identifiable as Agorophius but notably differ from the holotype of Agorophius

276 pygmaeus and SC 2015.51.1 in exhibiting an anteroposteriorly shorter exposure of the parietal in

277 dorsal view. In fact, in all specimens of Agorophius from the Chandler Bridge Formation (ChM

278 PV4256, CCNHM 1921, CCNHM 1922), the length of the parietal at the midline is only 11.9-

$27914.7 \%$ of the minimum parietal breadth at the intertemporal constriction. In crania from the

280 Ashley Formation (holotype, SC 2015.51.1), the parietal is somewhat anteroposteriorly longer

281 and constitutes $22-46.4 \%$ of the intertemporal width (Table 1). Another feature differentiating

282 ChM PV4256 from Agorophius pygmaeus is the presence of a triangular rather than parabolic or

283 convex apex of the occipital shield (Godfrey et al., 2016: 165). A triangular apex is also present

284 in CCNHM 1921 and 1922. Given that the holotype is from the late early Oligocene Ashley

285 Formation (Whitmore and Sanders, 1977; Godfrey et al., 2016), these consistent differences raise

286 the possibility that specimens from the late Oligocene Chandler Bridge Formation (including

287 ChM PV 4256) represent a geochronologically younger and as-yet undescribed species of

288 Agorophius. For the time being, CCNHM 1921, CCNHM 1922, and ChM PV4256 are

289 considered conspecific and identified as Agorophius sp., pending further study.

290 Ontogenetic trends are apparent within Chandler Bridge Agorophius sp. CCNHM 1922

291 and ChM PV4256 both possess open median frontal sutures and clear frontoparietal sutures; both

292 are mostly or totally closed in CCNHM 1921. CCNHM 1922 and ChM PV 4256 likely represent

293 similar ontogenetic stages, though neither are juveniles owing to their large size $(\sim 84-87 \%$

294 intertemporal width of CCNHM 1921; Fig. 3D, 4). Thus, we tentatively identify these specimens

295 as subadults and CCNHM 1921 as an adult. If correct, then ontogenetic trends within this species 
296 include a steeper occipital shield, an anteroposteriorly longer median dorsal exposure of the

297 frontal, an anteroposteriorly longer olfactory nerve canal, and blunted apex of an otherwise

298 triangular occipital shield apex in CCNHM 1921. Curiously, the ratio of the anteroposterior

299 length to transverse width of the parietal appears stable (anteroposterior length equals 6.25-

$3008.34 \%$ of transverse width) throughout this crude growth series (CCNHM 1921, 1922, ChM PV

301 4256), suggesting minimal change in parietal exposure during postnatal ontogeny.

302 Further questions arise regarding the size of reported Agorophius crania. A smaller

303 cranium from the Ashley Formation, ChM PV 5852, was tentatively considered to belong to

304 Agorophius by Geisler and Sanders (2003) and identified as Agorophius sp. by Deméré et al.

305 (2005). In fact, Geisler and Sanders (2016) recovered a sister-group relationship between ChM

306 PV4256, which all studies agree can be referred to Agorophius (Geisler and Sanders, 2003;

307 Godfrey et al., 2016), and ChM PV5852 in some of their phylogenetic analyses. Godfrey et al.

308 (2016) considered this specimen as Odontoceti indet. because they recovered it as the sister

309 taxon of Simocetus rayi. Although those authors did not report support values, the same

310 relationship was also recovered by Lambert et al. (2017), and the branch support for this

311 relationship was low. Thus we consider the generic attribution of ChM PV5852 a question that

312 requires further investigation.

313 This cranium of ChM PV5852 measures $186.8 \mathrm{~mm}$ in bizygomatic width, slightly smaller

314 than SC 2015.51.1 (206 mm) and the holotype of Agorophius pygmaeus (approximately 190

$315 \mathrm{~mm})$. ChM PV 5852, SC 2015.51.1, and the holotype cranium are all much smaller than ChM

316 PV 4256 (248 mm). Newly referred crania CCNHM 1921 and 1922 lack squamosals but are

317 similar to ChM PV4256 in intertemporal width. Whereas the holotype specimen exhibits a

318 number of open and incipiently fused cranial sutures indicating immaturity, ChM PV 5852 does 
319 not and has a greater degree of suture closure than one of the skulls reported here (CCNHM

320 1921), suggesting the presence of a large and small morphotype of Agorophius (if ChM PV5852

321 is a species of Agorophius) If correct, then SC 2015.51.1 and ChM PV 5852 represent a small

322 morph and ChM PV 4256, CCNHM 1921, and CCNHM 1922 all represent a much larger morph.

323 However, owing to fact that the holotype is immature and smaller than adults of each

324 morphotype, it is unclear which, if any, of these morphotypes represents Agorophius pygmaeus.

325 Formal description of ChM PV 5852 and recently discovered Agorophius-like crania from the

326 Ashley Formation is required to resolve these questions.

327

\section{Conclusions}

329 New specimens of Agorophius include two fragmentary crania preserving the intertemporal region and 'vertex' and constitute the first formally described remains of this odontocete from the Chandler Bridge Formation. These specimens share with Agorophius pygmaeus an intertemporal constriction, pointed occipital shield, and a flattened frontal-occipital 'table' in lateral view. The broken nature of these specimens reveals that Agorophius had a cribriform plate and large ethmoturbinal recess, suggesting a well-developed olfactory sense. The larger size and proportionally shorter exposure of parietal at the midline suggests that there are in fact two species of Agorophius, which differ in size. A better understanding of cranial is almost certainly an immature individual.

\section{Acknowledgements}


First and foremost we thank S. Hildenbrandt for collecting the cetacean specimens

342

343

344

345

346

347

348

349

350

351

352

353

354

355

356

357

358

359

360

361

362

reported within, and M. Brown for donating the specimens to CCNHM. This study benefited

from discussions with B.L. Beatty, S.J. Boessenecker, M. Churchill, M. Gibson, and A.E.

Sanders. Thanks to S. Boessenecker (CCNHM) and M. Gibson and J. Peragine (ChM) for access

to specimens under their care. Thanks to Stephen J. Godfrey, an anonymous reviewer, and the editor J.G.M. Thewissen for critical comments which improved the quality of this paper.

\section{References Cited}

Berta A., Ekdale EG, Cranford TW. 2014. Review of the cetacean nose: form, function, and evolution. The Anatomical Record 297(11): 2205-2215.

Boessenecker RW, Ahmed E, Geisler JH. 2017a. New records of the dolphin Albertocetus meffordorum (Odontoceti: Xenorophidae) from the lower Oligocene of South Carolina: encephalization, sensory anatomy, postcranial morphology, and ontogeny of early odontocetes. PLoS ONE. 12(11):e0186476.

Boessenecker RW, Fraser D, Churchill M, Geisler JH. 2017b. A toothless dwarf dolphin (Odontoceti: Xenorophidae) points to explosive feeding diversification of modern whales (Neoceti). Proceedings of the Royal Society B. 284(1861):20170531.

Churchill M, Martinez-Caceres M, Muizon Cd, Mnieckowski J, Geisler JH. 2016. The origin of high-frequency hearing in whales. Current Biology. 26(16):2144-2149.

Cicimurri DJ, Knight JL. 2009. Late Oligocene sharks and rays from the Chandler Bridge Formation, Dorchester County, South Carolina, USA. Acta Palaeontologica Polonica. $54: 627-647$. 
363 Deméré TA, Berta A, McGowen MR. 2005. The taxonomic and evolutionary history of modern

364 balaenopteroid mysticetes. Journal of Mammalian Evolution. 12(1/2):99-143.

365

366

367

368

369

370

371

372

373

374

375

376

377

378

379

380

381

382

383

384

385

Domning DP. 1997. Fossil Sirenia of the West Atlantic and Caribbean Region. IV. Crenatosiren olseni (Reinhardt, 1976). Journal of Vertebrate Paleontology. 17(2):397-412.

Edinger T. 1955. Hearing and smell in cetacean history. Monatsschrift fur Psychiatrie und Neurologie. 129:37-58.

Erickson BR, Sawyer GT. 1996. The estuarine crocodile Gavialosuchus carolinensis n. sp. (Crocodylia: Eusuchia) from the late Oligocene of South Carolina. Monograph of the Science Museum of Minnesota. 3:1-47.

Fierstine HL, Weems RE. 2009. Paleontology of the Oligocene Ashley and Chandler Bridge Formations of South Carolina, 4: analysis and new records of billfishes (Perciformes: Ziphiodei). Palaeo Ichthyologica. 11:43-88.

Fordyce RE. 1981. Systematics of the odontocete whale Agorophius pygmaeus and the family Agorophiidae (Mammalia: Cetacea). Journal of Paleontology. 55(5):1028-1045.

Geisler JH, A.E. S. 2003. Morphological evidence for the phylogeny of Cetacea. Journal of Mammalian Evolution. 10(1/2):23-129.

Geisler JH, Colbert MW, Carew JL. 2014. A new fossil species supports an early origin for toothed whale echolocation. Nature. 508:383-386.

Godfrey SJ. 2013. On the olfactory apparatus in the Miocene odontocete Squalodon sp. (Squalodontidae). Comptes Rendus Palevol. 12:519-530.

Godfrey SJ, Geisler JH, Fitzgerald EMG. 2013. On the olfactory anatomy in an archaic whale (Protocetidae, Cetacea) and the minke whale Balaenoptera acutorostrata (Balaenopteridae, Cetacea). The Anatomical Record. 296:257-272. 
386 Godfrey SJ, Uhen MD, Osborne JE, Edwards LE. 2016. A new specimen of Agorophius

387

388

389

390

391

392

393

394

395

396

397

398

399

400

401

402

403

404

405

406

407

pygmaeus (Agorophiidae, Odontoceti, Cetacea) from the early Oligocene Ashley

Formation of South Carolina, USA. Journal of Paleontology. 90:154-169.

Katuna MP, Geisler JH, Colquhoun DJ. 1997. Stratigraphic correlation of Oligocene marginal marine and fluvial deposits across the middle and lower coastal plain, South Carolina. Sedimentary Geology. 108:181-194.

Kidwell SM. 1993. Influence of subsidence on the anatomy of marine siliciclastic sequences and on the distribution of shell and bone beds. Journal of the Geological Society, London. 150:165-167.

Kishida T, Kubota S, Shirayama Y, Fukami H. 2007. The olfactory receptor gene repertoires in secondary-adapted marine vertebrates: evidence for reduction of the functional proportions in cetaceans. Biology Letters. 3(4): 428-430.

Ksepka DT. 2014. Flight performance of the largest volant bird. Proceedings of the National Academy of Sciences. 111(29):10624-10629.

McGowen MR, Clark C, Gatesy J. 2008. The vestigial olfactory receptor subgenome of odontocete whales: phylogenetic congruence between gene-tree reconciliation and supermatrix methods. Systematic Biology 57(4): 574-590.

Mead JG, Fordyce RE. 2009. The therian skull: a lexicon with emphasis on the odontocetes. Smithsonian Contributions to Zoology. 627:1-248.

Purdy RW, Schneider VP, Applegate SP, McLellan JH, Meyer RL, Slaughter BH. 2001. The Neogene sharks, rays, and bony fishes from Lee Creek Mine, Aurora, North Carolina. Smithsonian Contributions to Paleobiology. 90:71-202. 
408 Sanders AE, Barnes LG. 2002. Paleontology of the Late Oligocene Ashley and Chandler Bridge

409

410

411

412

413

414

415

416

417

418

419

420

421

422

423

424

425

426

427

428

429

Formations of South Carolina, 3: Eomysticetidae, a new family of primitive mysticetes

(Mammalia: Cetacea). Smithsonian Contributions to Paleobiology. 93:313-356.

Sanders AE, Geisler JH. 2015. A new basal odontocete from the upper Rupelian of South Carolina, USA, with contributions to the systematics of Xenorophus and Mirocetus (Mammalia, Cetacea). Journal of Vertebrate Paleontology. 35(1): e890107.

Sanders AE, Weems RE, Lemon EMj. 1982. Chandler Bridge Formation - a new Oligocene stratigraphic unit in the lower coastal plain of South Carolina. US Geological Survey Bulletin. 1529-H:H105-H124.

Springer MS, Gatesy J. 2017. Inactivation of the olfactory marker protein (OMP) gene in river dolphins and other odontocete cetaceans. Molecular Phylogenetics and Evolution 109: $375-387$.

Thewissen JGM, George J, Rosa C, Kishida T. 2011. Olfaction and brain size in the bowhead whale (Balaena mysticetus). Marine Mammal Science 27(2): 282-294.

Velez-Juarbe J, Domning DP. 2014a. Fossil Sirenia of the West Atlantic and Caribbean Region. IX. Metaxytherium albifontanum, sp. nov. Journal of Vertebrate Paleontology. 34(2):444464.

Velez-Juarbe J, Domning DP. 2014b. Fossil sirenia of the West Atlantic and Caribbean region. X. Priscosiren atlantica, gen et sp. nov. Journal of Vertebrate Paleontology. 34(4):951964.

Weems RE, Brown KM. 2017. More-complete remains of Procolpochelys charlestonensis (Oligocene, South Carolina) an occurrence of Euclastes (upper Eocene, South Carolina), 
430

431

432

433

434

435

436

437

438

439

440

441

442

443

444

445

446

447

448

449

450

451

452

and their bearing on Cenozoic pancheloniid sea turtle distribution and phylogeny. Journal of Paleontology. 91(6):1228-1243.

Weems RE, Bybell LM, Edwards LE, Lewis WC, Self-Trail JM, Albright LB, III,, Cicimurri DJ, Harris WB, Osborne JE, Sanders AE. 2016. Stratigraphic revision of the Cooper Group and Chandler Bridge and Edisto Formations in the coastal plain of South Carolina. South Carolina Geology. 49:1-24.

Weems RE, Knight JL. 2013. A new species of Bairdemys (Pelomedusoides: Podocnemididae) from the Oligocene (early Chattian) Chandler Bridge Formation of South Carolina, USA, and its paleobiogeographic implications for the genus. In: Brinkman DB, Holroyd PA, Gardner JD, editors. Morphology and Evolution of Turtles. Dordrecht: Springer; p. 289303.

Weems RE, Lewis WC. 2002. Structural and tectonic setting of the Charleston, South Carolina region: evidence from the Tertiary stratigraphic record. Geological Society of America Bulletin. 114:24-42.

Weems RE, Sanders AE. 2014. Oligocene pancheloniid sea turtles from the vicinity of Charleston, South Carolina, U.S.A. Journal of Vertebrate Paleontology. 34(1):80-99.

Whitmore FC, Sanders AE. 1977. A review of the Oligocene Cetacea. Systematic Zoology. 25:304-320.

\section{Figures}

Figure 1. Geographic and geologic context of Agorophius sp. specimens in South Carolina (A). Generalized geologic map of Oligocene strata in the Charleston area with star indicating the locality that produced CCNHM 1921 and 1922 (B), map modified from Weems and Lewis (2002) and Boessenecker et al. (2017a); (C) idealized stratigraphic section of the 
453

454

455

456

457

458

459

460

461

462

463

464

465

466

Chandler Bridge Formation, with silhouette indicating bed that produced the new specimens, modified from Katuna et al. (1997).

Figure 2. Skulls of Agorophius sp. (CCNHM 1921, 1922) from the Chandler Bridge Formation (A-E); CCNHM 1922 in dorsal view (A); CCNHM 1921 in dorsal view (B); line drawings of CCNHM 1922 and 1921 in dorsal view (C, D); CCNHM 1922 in ventral view (E); CCNHM 1921 in ventral view (F). Abbreviations: fr, frontal; m, maxilla; n, nasal; p, parietal; px, premaxilla; so, supraoccipital.

Figure 3. Skulls of Agorophius sp. in lateral view; CCNHM 1922 (A, left lateral), and CCNHM 1921 (B, right lateral); size comparison of Agorophius spp. Crania in dorsal view (C); scatterplot of parietal width and parietal length at the midline, in millimeters (D). Closed circles denote specimens from the Ashley Formation and open circles denote specimens from the Chandler Bridge Formation.

Figure 4. Skull of Agorophius sp. (CCNHM 1922) in anterior view (A) and a view of the olfactory peduncle canal and cribriform plate in posteroventral view (B). 


\section{Table 1 (on next page)}

Measurements of the intertemporal constriction of Agorophius. 
1 Table 1. Measurements of the intertemporal constriction of Agorophius.

\begin{tabular}{|l|l|l|l|}
\hline Specimen & $\begin{array}{l}\text { Minimum Parietal } \\
\text { width }(\mathrm{mm})\end{array}$ & $\begin{array}{l}\text { Anteroposterior } \\
\text { length of Parietal at } \\
\text { midline }(\mathrm{mm})\end{array}$ & $\begin{array}{l}\text { Parietal } \\
\text { width/parietal length }\end{array}$ \\
\hline MCZ 8761 & 49.5 & 23 & $46.46 \%$ \\
\hline SC 2015.51.1 & 54 & 11.9 & $22.04 \%$ \\
\hline ChM PV 4256 & 72 & 4.5 & $6.25 \%$ \\
\hline ChM PV 5852 & 66.1 & 10.5 & $15.89 \%$ \\
\hline CCNHM 1921 & 74.5 & 6.2 & $8.32 \%$ \\
\hline CCNHM 1922 & 85.1 & 7.1 & $8.34 \%$ \\
\hline
\end{tabular}

2 
Figure 1

Geographic and geologic context of Agorophius sp. specimens in South Carolina (A)

Generalized geologic map of Oligocene strata in the Charleston area with star indicating the locality that produced CCNHM 1921 and 1922 (B), map modified from Weems and Lewis (2002) and Boessenecker et al. (2017a); (C) idealized stratigraphic section of the Chandler Bridge Formation, with silhouette indicating bed that produced the new specimens, modified from Katuna et al. (1997).
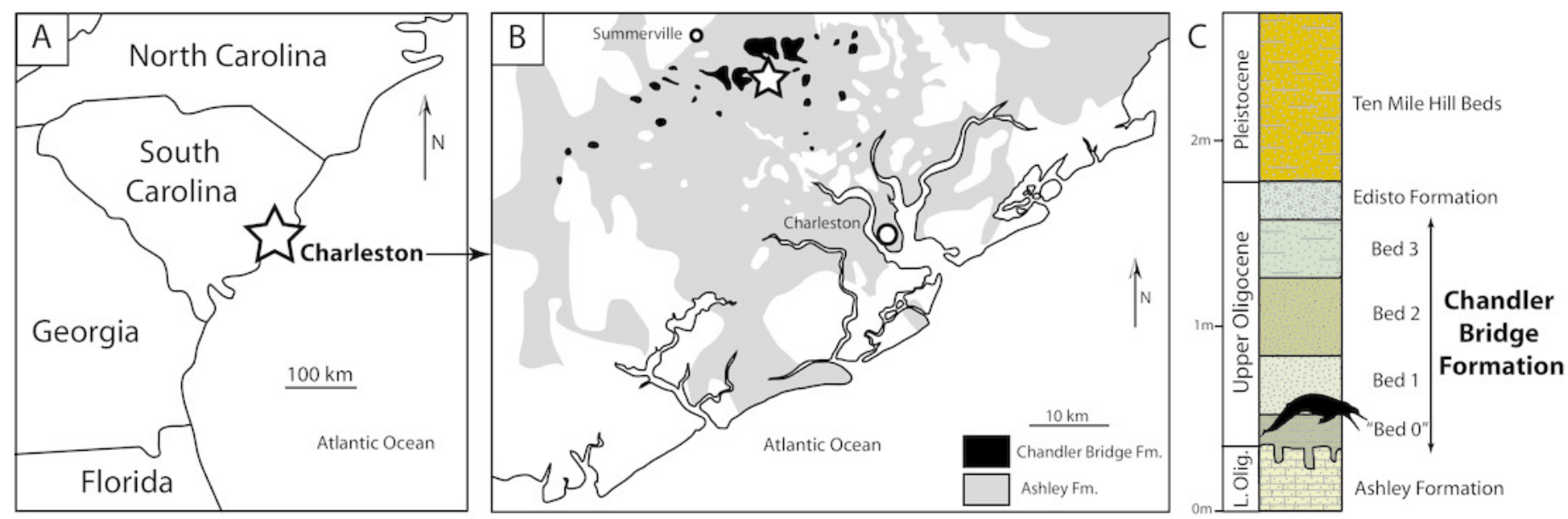


\section{Figure 2}

Skulls of Agorophius sp. (CCNHM 1921, 1922) from the Chandler Bridge Formation (A-E;

CCNHM 1922 in dorsal view (A); CCNHM 1921 in dorsal view (B); line drawings of CCNHM 1922 and 1921 in dorsal view (C, D); CCNHM 1922 in ventral view (E); CCNHM 1921 in ventral view. Abbreviations: fr, frontal; $m$, maxilla; $n$, nasal; p, parietal; px, premaxilla; so, supraoccipital. 


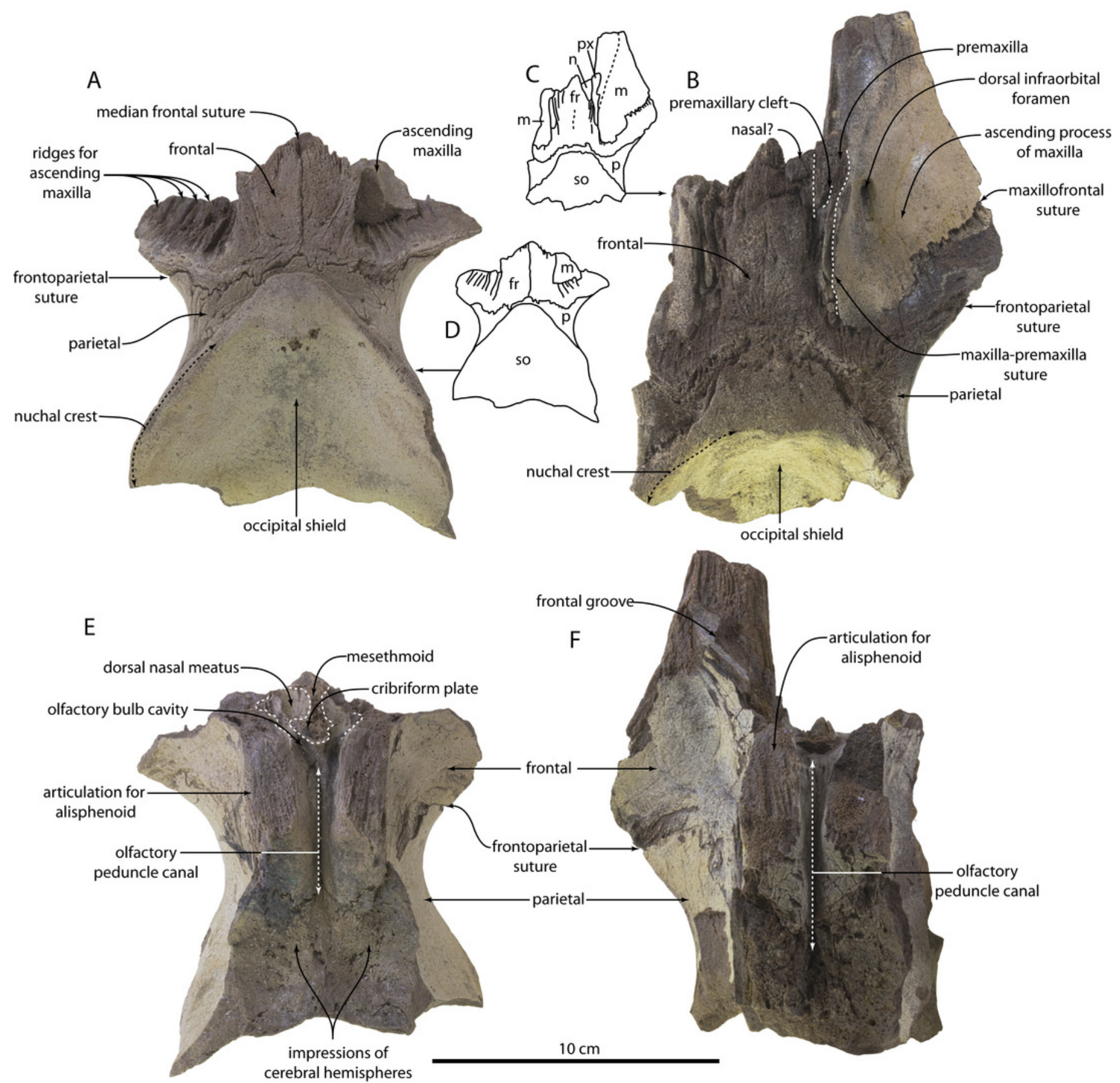


Figure 3

Skulls of Agorophius sp. in lateral view

CCNHM 1922 (A), and CCNHM 1921 (B); size comparison of Agorophius spp. Crania in dorsal view (C); scatterplot of parietal width and parietal length at the midline, in millimeters (D). Closed circles denote specimens from the Ashley Formation and open circles denote specimens from the Chandler Bridge Formation.

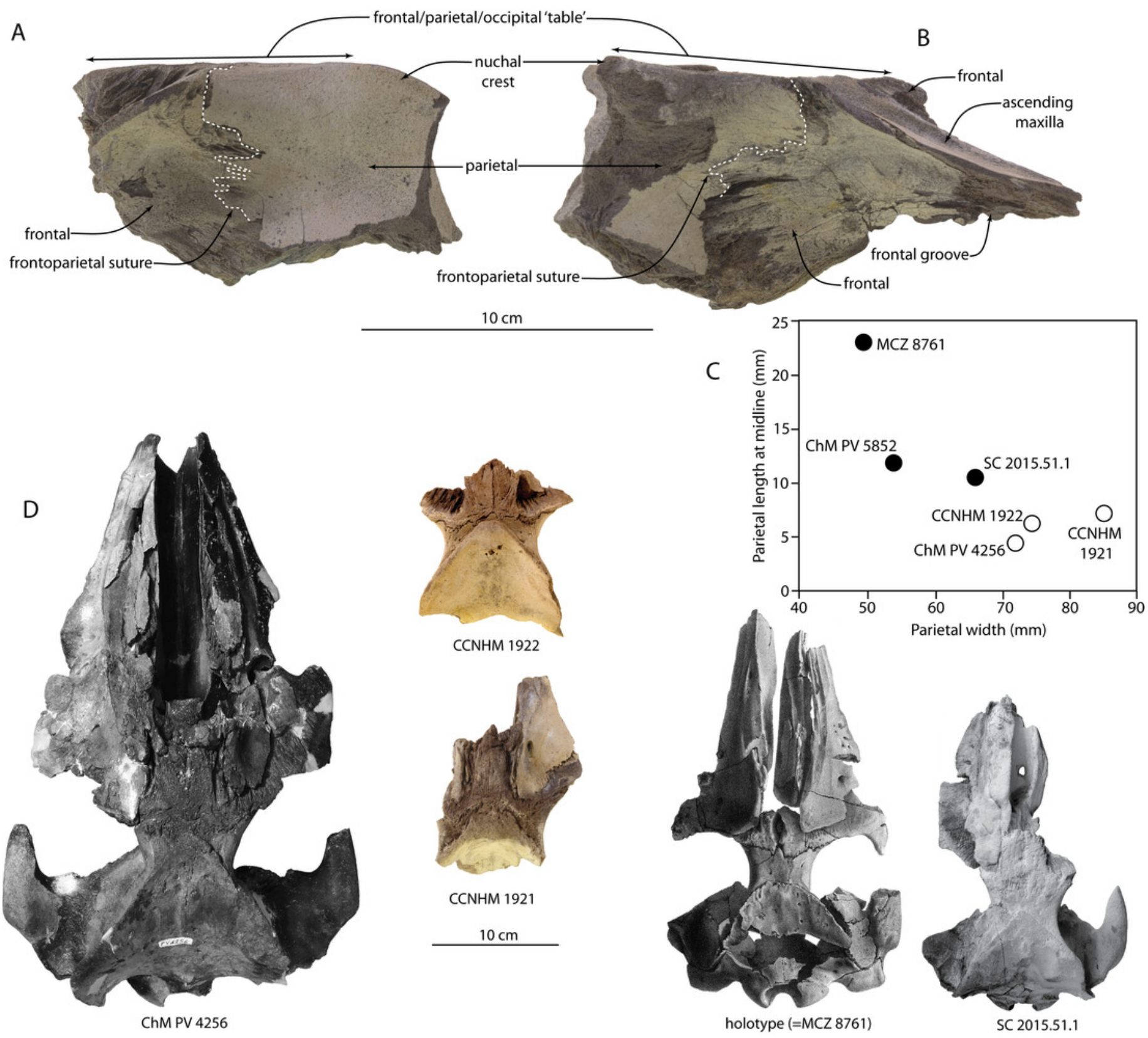




\section{Figure 4}

Skull of Agorophius sp. (CCNHM 1922) in anterior view.

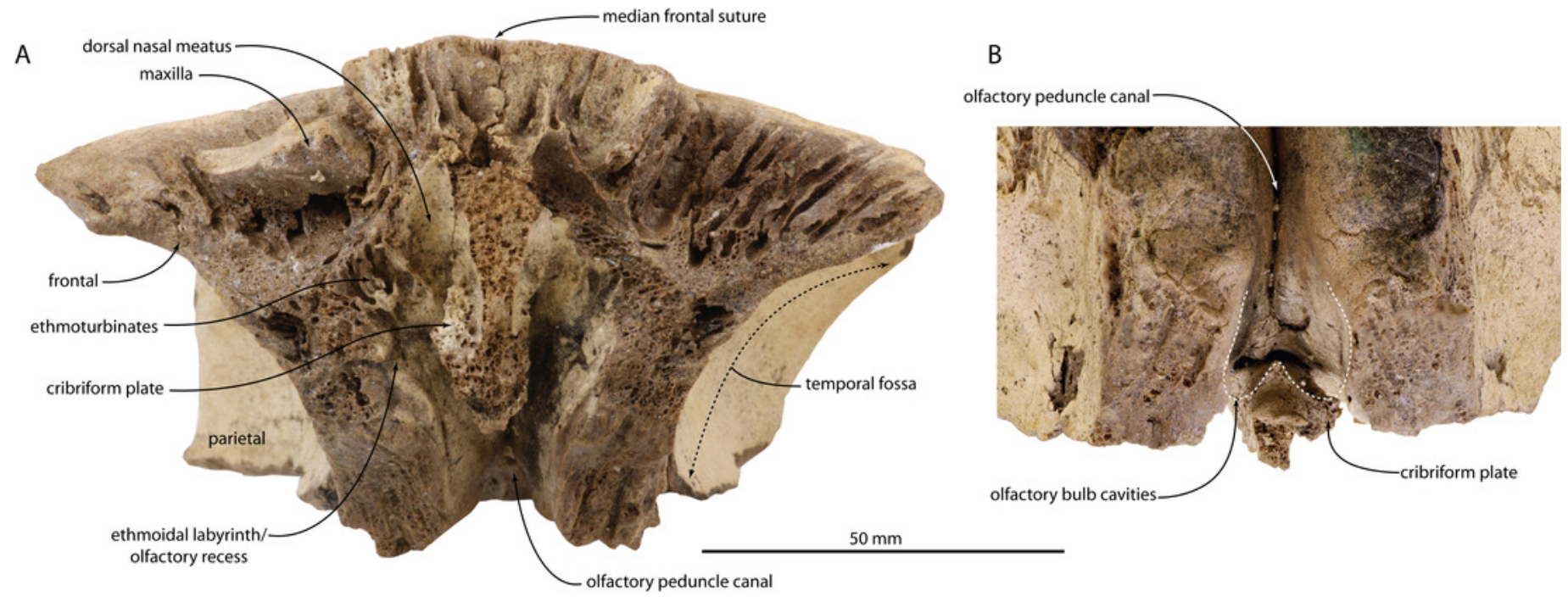

